\title{
Intensitas dan Variasi Morfometrik Trichodina sp. pada Benih Ikan Gurami (Osphronemus gouramy Lacepede) Pendederan I yang Dijual di Pasar Ikan Purwonegoro Kabupaten Banjarnegara
}

\author{
Nurul Anisah', Rokhmani ${ }^{1}$ Dan Edy Riwidiharso ${ }^{1}$ \\ ${ }^{1}$ Fakultas Biologi, UniversitasJenderal Soedirman \\ Email : rokhmanitatiek@gmail.com
}

\begin{abstract}
Purwonegoro Fish Market in Banjarnegara district is the largest fish market in southern and western Central Java. This fish market serves as a center for buying and selling fish and fish fry traffic in a particular place to the location of the fish farmers. This activity possibly spreads a particular type of disease from one area to another. Trichodina sp. is found on gouramy fish fry in hatchery center area with the pathogenicity level of $80 \%$. Trichodina sp. has a big impact in the gouramy farming by dangerously reduces the physical condition of the fish and cause death of gouramy fry. The results showed that as many as 56 gouramy fish fry were infected by Trichodina sp. from 150 gouramy fish fry examined. Total number of Trichodina sp. found was 573 individual from the infected gouramy fry. Total intensity of Trichodina sp. of gouramy fry was 10,97 individual/fish. The morphometric characters measurement of Trichodina sp. showed morphometric variation with the range of body diameter 47,5 -112,5 $\mu \mathrm{m}$; denticle ring diameter 22,5 - 47,5 $\mu \mathrm{m}$; denticle diameter $12,5-42,5 \mu \mathrm{m}$, adhesive disc diameter $37,5-65 \mu \mathrm{m}$; membrane width $2,5-7,5 \mu \mathrm{m}$ and the number of denticle $13-28$. Trichodina sp. allegedly found were T. heterodentata, T. nigra, and T. acuta.
\end{abstract}

Key Words : gouramy, Trichodina sp., intensity, morphometric variation.

\begin{abstract}
Abstrak
Pasar Ikan Purwonegoro, Kabupaten Banjarnegara merupakan pasar ikan terbesar se-Jawa Tengah bagian selatan dan barat. Pasar ikan ini berfungsi sebagai sentra jual beli ikan dan lalu lintas benih ikan di tempat tertentu ke lokasi petani ikan. Hal ini tidak menutup kemungkinan akan menyebarnya suatu jenis penyakit tertentu dari satu daerah ke daerah lain. Trichodina sp. ditemukan hampir di seluruh wilayah sentra jual-beli ikan gurami dengan tingkat patogenisitas mencapai $80 \%$. Trichodina sp. memiliki peran besar dalam produksi budidaya ikan gurami dengan cara menurunkan kondisi fisik ikan sehingga membahayakan dan menimbulkan kematian ikan gurami pada fase benih. Hasil penelitian menunjukkan bahwa sebanyak 150 ekor benih ikan gurami yang diperiksa, 56 ekor benih yang terinfeksi Trichodina sp. Jumlah Trichodina sp. yang ditemukan sebanyak 573 individu dari benih yang terinfeksi. Intensitas total Trichodina sp. pada benih ikan gurami sebesar 10,97 individu/ekor dan tergolong cukup tinggi. Hasil pengukuran karakter morfometrik Trichodina sp. menunjukkan adanya variasi morfometrik dengan diameter tubuh

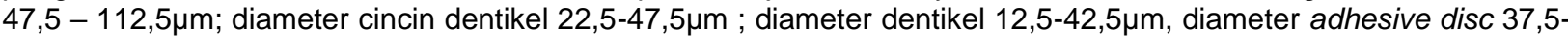
$65 \mu \mathrm{m}$; lebar membran $2,5-7,5 \mu \mathrm{m}$ dan jumlah dentikel 13-28. Trichodina sp. yang ditemukan diduga terdapat tiga jenis yaitu $T$. heterodentata, $T$. nigra, dan $T$. acuta.
\end{abstract}

Kata kunci: Gurami, Trichodina sp., intensitas, variasi morfometrik.

\section{Pendahuluan}

Pasar Ikan Purwonegoro Kabupaten Banjarnegara adalah lokasi atau tempat untuk aktivitas jual beli ikan air tawar di Banjarnegara. Lokasi Pasar ikan ini strategis karena terletak di jalur lalu lintas transportasi antar kabupaten dan antar provinsi, sehingga lebih memudahkan bagi pembeli dan penjual ikan dari dalam maupun luar daerah untuk menuju lokasi tersebut. Aktivitas jual beli ikan di Pasar Ikan Purwonegoro tidak hanya melibatkan penjual ikan dari dalam kabupaten Banjarnegara saja, namun juga ditemukan penjual ikan yang datang dari kabupaten Banyumas, Purbalingga serta Semarang (Himawati, 2011). Salah satu jenis ikan air tawar yang dijual di Pasar Ikan Purwonegoro, diantaranya ialah ikan gurami.

Ikan gurami (Osphronemus gouramy Lac.) jenis ikan air tawar yang mempunyai nilai ekonomi relatif tinggi karena rasa dagingya yang gurih, lezat, memiliki gizi yang tinggi sehingga banyak digemari masyarakat. Ikan gurami memiliki harga jual yang terus meningkat dan stabil sehingga menjadi pilihan pembudidaya ikan dibandingkan komoditas ikan air tawar lainnya. Pengembangan budidaya gurami tidak lepas dari beberapa kelemahan. Salah satu kelemahan pada budidaya gurami ukuran konsumsi yaitu memiliki laju pertumbuhan yang lambat. Akibat adanya kelemahan pada budidaya gurami ukuran konsumsi, menyebabkan banyaknya jumlah para pembudidaya ikan lebih memilih usaha pembenihan karena biaya produksi yang lebih murah, tidak memerlukan waktu yang cukup lama serta apabila dijual keuntungan yang diperoleh cukup banyak. Namun dalam budidaya ikan gurami pada ukuran benih sering kali dihadapkan pada beberapa kendala, salah satunya adalah infeksi serangan parasit. Infeksi parasit 
merupakan salah satu kendala yang sering terjadi dalam usaha budidaya ikan gurami, terutama dalam fase pembenihan, karena pada fase ini sistem pertahanan tubuh gurami belum sempurna. Parasit adalah organisme yang hidup di dalam atau pada tubuh organisme lain, mendapat makanan untuk hidupnya dan dapat mengakibatkan beberapa kerugian pada inangnya. Parasit pada ikan membutuhkan kondisi lingkungan yang dapat mendukung pertumbuhan dan perkembangan hidupnya. Kondisi tersebut berupa kualitas air yang buruk, banyaknya bahan organik dalam kolam, kondisi air yang tergenang, fluktuasi suhu yang drastis, suhu yang rendah dan padat penebaran kolam yang tinggi. Selain itu jumlah inang tertentu juga dibutuhkan untuk kelangsungan hidup parasit. Kenaikan jumlah inang pada suatu kolam akan menaikkan jumlah penyebaran parasit pada inang.

Berdasarkan manifestasi keparasitannya, parasit dapat dibedakan menjadi 2, yaitu endoparasit dan ektoparasit. Endoparasit adalah parasit yang menginfeksi bagian dalam tubuh ikan, baik organ dalam maupun jaringan otot. Beberapa endoparasit yang biasa ditemukan pada ikan, antara lain Anisakis spp., Ascarophis sp., dan Philonema sp. Sedangkan, ektoparasit merupakan parasit yang hidup pada permukaan tubuh inang dan memperoleh makanandari inangnya. Penelitian Himawati (2011), terdapat berbagai jenis ektoparasit yang menginfeksi benih ikan gurami yang didapatkan dari Pasar Ikan Purwonegoro Kabupaten Banjarnegara yaitu Oodinium sp., Chilodonella sp, Gyrodactylus sp., Dactylogyrus sp.Epistylis sp., dan Trichodina sp. Trichodina sp. merupakan parasit patogen yang paling banyak ditemukan pada benih ikan gurami di Pasar Ikan Purwonegoro. Penyakit yang disebabkan parasit dari familia Trichodinidae ini dikenal dengan nama Trichodiniasis atau penyakit gatal pada ikan. Trichodina sp. pada ikan air tawar maupun air laut sering ditemukan menginfeksi kulit dan menyebabkan kerusakan berat pada insang sehingga dapat menyebabkan kematian (Woo, 2006 ). Pengaruh Trichodiniasis yang berbahaya adalah akibat dari pergerakan Trichodinanya, sehingga setiap individu dapat menyebar ke wilayah yang luas. Trichodina sp. dapat hidup lebih dari dua hari tanpa inang. Ikan yang terinfeksi Trichodina sp. menunjukkan warna pucat, iritasi kulit, hiperplasia, degenerasi dan nekrosis dari sel epitel yang muncul bersamaan dengan proliferasi dari sel lendir sehingga semakin lama ikan menjadi lemah dan kurus, selanjutnya ikan akan mati (Rohkmani, 2009). Salah satu faktor yang mempengaruhi keberadaan Trichodina sp. antara lain kandungan partikel-partikel organik dan jumlah bakteri dalam perairan. Lingkungan dengan kandungan bahan organik tinggi merupakan kondisi yang sangat disukai oleh Trichodina, disamping merupakan faktor pemicu tingginya jumlah bakteri dalam perairan melalui mekanisme dekomposisi. Keduahal tersebut secara bersama-sama akan menyebabkan prevalensi dan intensitas Trichodina sp. meningkat karena terdapat sumber makanan yang cukup banyak bagi Trichodina sp. dan terjadinya penurunan kondisi ikan. Keadaan ini akan menjadi lebih parah jika ikan ditebar dengan padat penebaran tinggi sehingga sangat memungkinkan terjadinya infeksi akut oleh parasit ini (Nugrayani et al, 2011).

Intensitas serangan adalah jumlah rata-rata individu suatu spesies parasit dibagi dengan jumlah inang yang terinfeksi (Kabata, 1985). Nilai intensitas digunakan untuk mengetahui tingkat serangan infeksi pada ikan budidaya. Intensitas dalam jumlah sedikit maupun melimpah dapat menyebabkan gangguan pada tubuh ikan, namun intensitas gangguan tersebut tergantung pada jenis ikan, stadia ikan, dan kondisi ikan. Kondisi ikan stress karena pemindahan lokasi dapat menurunkan daya tahan tubuh ikan dan biasanya ikan lebih mudah terserang penyakit. Intensitas serangan parasit dalam jumlah besar dapat menimbulkan kematian pada ikan dan mengganggu produktivitas budidaya ikan.

Trichodina sp. yang ditemukan pada masingmasing tubuh ikan memiliki karakter morfometrik yang berbeda. Perbedaan morfologi Trichodina sp. dapat diketahui melalui karakter morfometrik yang meliputi ukuran diameter tubuh, diameter cincin dentikel, diameter adhesive disc, lebar membran dan karakter morfometrik yaitu jumlah dentikel (Dana et al., 2002). Variasi morfometrik Trichodina sp. berkaitan dengan jumlah dan jenis Trichodina sp. yang ditemukan, dengan ukuran yang bervariasi (Basson \& Van As, 2006). Variasi struktur dan morfologiTrichodina sp. pada sentra benih ikan gurami di Wilayah Kabupaten Banyumas, Kabupaten Purbalingga, dan Kabupaten Banjarnegara diduga berkaitan dengan penyebaran benih ikan gurami ke seluruh Provinsi Jawa Tengah yang memiliki perbedaan kondisi lingkungan lokasi sentra benih dan budidaya ikan gurami (temperatur, lingkungan, kondisi fisik, dan kimiawi perairan), sehingga menyebabkan bervariasinya kemampuan dan perkembangan ikan gurami maupun Trichodina sp. sebagai ektoparasitnya (Rokhmani et al., 2015).

Salah satu karakter ukuran morfometrik Trichodina sp. berupa ujung dentikel. Ujung dentikel Trichodina sp. ada dua jenis, yaitu ujung berbentuk tumpul dan ujung berbentuk lancip. Hasil pengamatan karakteristik morfometrik Trichodina sp. yang dilakukan Utami (2015) pada benih ikan gurami dari kolam budidaya Desa Luwung, Kecamatan Rakit, Banjarnegara menunjukkan bahwa pada benih ikan gurami tersebut terdapat dua jenis perbedaan morfologi Trichodina sp. yaitu Trichodina nobilis dan Trichodina reticulata. Selanjutnya hasil penelitian Amirudin (2015), menemukan ektoparasit pada benih ikan gurami pendederan II yang dijual di TPI 
Purbalingga terdapat variasi morfometrik Trichodina sp. yang diduga spesies Trichodina acuta, Trichodina heterodentata, Trichodina magna, dan Trichodina nobilis. Trichodina nobilis merupakan Trichodina yang memiliki ujung dentikel yang berbentuk lancip sedangkan Trichodina reticulata memiliki ujung dentikel tumpul (Windarto et al. (2013).

Berdasarkan latar belakang tersebut, maka diajukan permasalahan yang perlu dikaji adalah bagaimanakah intensitas dan variasi morfometrik parasit Trichodina sp. yang menginfeksi benih ikan gurami umur pendederan I dari salah satu pedagang di Pasar Ikan Purwonegoro Kabupaten Banjarnegara.

Adapun tujuan dari penelitian ini adalah untuk mengetahui intensitas parasit Trichodina sp. yang menginfeksi benih gurami umur pendederan I yang dijual di Pasar Ikan Purwonegoro, Kabupaten Banjarnegara. Dan mengetahui variasi morfometrik Trichodina sp. yang menginfeksi benih gurami umur pendederan I yang dijual di Pasar Ikan Purwonegoro, Kabupaten Banjarnegara. Manfaat dari penelitian ini diharapakan dapat memantau tingkat serangan parasit ini dan diketahui jenis parasit ini, yang selanjutkan dapat dijadikan sebagai landasan dalam upaya pengendalian penyakit secara dini pada usaha budidaya ikan gurami.

\section{Metode Penelitian}

Sampel ikan diambil di $\begin{gathered}\text { Pasar Ikan } \\ \text { Purwonegoro }\end{gathered}$ Kabupaten
Banjarnegara. Pemeriksaan Trichodina sp. dari benih ikan gurami dilakukan di Laboratorium EntomologiParasitologi Fakultas Biologi Universitas Jenderal Soedirman. Teknik Pengambilan Sampel pada penelitian ini dilakukan dengan metode survai dengan pengambilan sampel benih ikan menggunakan teknik random sampling. Pengambilan sampel ikan dilakukan tiga kali dengan selang waktu satu minggu. Jumlah sampel benih ikan yang diambil adalah 150 ekor benih ikan yang dijual di Pasar Ikan Purwonegoro, Banjarnegara. Pengukuran karakteristik morfometrik Trichodina sp. dilakukan secara sampling dari benih ikan yang terinfeksi. Organ tubuh ikan yang diamati adalah sirip ekor, sirip punggung, sirip dada,sirip anal, insang dan lendir. Waktu penelitian Januari sampai April 2016.

\section{Cara Kerja}

\section{Pembuatan Preparat untuk Pengamatan Trichodina sp.}

Sirip dada, sirip dorsal, sirip anal, dan sirip ekor dari benih ikan dipisahkan/diupotong dengan cara digunting, kemudian diletakkan secara membujur di atas object glass. Bagian lendir dari tubuh ikan juga dibuat preparat dengan cara dikerok menggunakan scalpel. Lendir kemudian diusap di atas object glass. Gelas preparat kemudian dijemur di bawah sinar matahari langsung sampai preparat mengering.Setelah kering, gelas preparat yang terdapat potongan sirip, insang, dan lendir direndam larutan AgNO3 $2 \%$ selama 10 menit, kemudian dibilas dengan akuades. Gelas preparat kemudian disinari dengan sinar ultra violet (UV) selama 15-20 menit.

\section{Identifikasi dan Perhitungan Jumlah Trichodina sp.}

Preparat diamati dan diidentifikasi ada tidaknya Trichodina sp. menggunakan mikroskop dengan perbesaran 1000 kali. Morfologi Trichodina sp. diidentifikasi berdasarkan petunjuk Kabata (1985). Preparat Trichodina sp. diamati pada tiap bagian organ menggunakan mikroskop dengan perbesaran 100 kali. Jumlah total individu Trichodina sp. dihitung pada seluruh ikan sampel yang terinfeksi.Jumlah intensitas Trichodina sp. dihitung pada seluruh ikan yang terinfeksi.

\section{Pengukuran Karakteristik Morfometrik Trichodina sp.}

Preparat Trichodina sp. diamati dengan menggunakan mikrometer okuler dan mikrometer objektif yang dipasangkan pada mikroskop dengan perbesaran 400 kali.Karakteristik morfometrik Trichodina sp. diamati dengan mengukur diameter tubuh, diameter cincin dentikel, jumlah dentikel, lebar membran dan diameter adhesive disc. Data hasil pengukuran morfometrik dianalisis secara deskriptif berdasarkan petunjuk Basson (2010); dan Woo (2006).

\section{Analisis Data}

Intensitas Trichodina sp. yang ditemukan pada pada benih ikan sampel dihitung menurut Woo (2006)), berdasarkan rumus sebagai berikut Intensitas = Jumlah individu Trichodina sp yang ditemukan Jumlah ikan yang terinfeksi

Data variasi morfometrik dianalisis secara deskriptif menurut Basson (2010); Woo (2006).

\section{Hasil dan Pembahasan}

Hasil penelitian ektoparasit Trichodina $\mathrm{sp}$. pada setiap benih ikan gurami pendederan I yang dijual di Pasar Ikan Purwonegoro dapat dilihat pada tabel 1. 
Tabel 1 Data Intensitas dan Prevalensi Trichodina sp. yang menginfeksi benih ikan gurami pendederan 1 di Pasar ikan Purwonegoro

\begin{tabular}{lllllll}
\hline \multicolumn{1}{c}{ Ulang } & $\begin{array}{c}\text { Jumla } \\
\text { h Ikan }\end{array}$ & $\begin{array}{c}\text { Benih } \\
\text { Terinfeksi }\end{array}$ & $\begin{array}{c}\text { Benih tidak } \\
\text { terinfeksi }\end{array}$ & $\begin{array}{c}\text { Trichodina sp. } \\
\text { yang ditemukan }\end{array}$ & $\begin{array}{c}\text { Intensitas } \\
\text { (individu/ekor) }\end{array}$ & Prevalensi (\%) \\
\hline I & 50 & 26 & 24 & 281 & 10,92 & 52 \\
II & 50 & 20 & 30 & 144 & 7,2 & 40 \\
III & 50 & 10 & 40 & 148 & 14,8 & 20 \\
Jumlah & 150 & 56 & 94 & 573 & 32,92 & 112 \\
\hline Rata-rata & & & & 10,97 & 37,33 \\
\hline
\end{tabular}

Berdasarkan table 1 dapat diketahui bahwa intensitas serangan infeksi Trichodina sp. pada benih ikan gurami sebesar 10,97 individu/ekor. Hal ini menunjukkan bahwa terdapat \pm 10 individu ektoparasit yang menginfeksi satu ekor benih ikan gurami. Nilai tersebut lebih rendah dibandingkan intensitas benih ikan gurami pendederan I yang terserang Trichodina sp. menurut Utami (2015) yaitu sebesar 100-120 individu//ekor dan hasil penelitian Nurochmah (2016) dengan intensitas mencapai 60,35 individu/ekor. Hasil penelitian intensitas Trichodina sp. pada benih ikan gurami ini memiliki nilai intensitas yang lebih tinggi dibandingkan dengan hasil penelitian intensitas Trichodina sp. pada benih ikan gurami pendederan II yang dilakukan Amirudin (2015) yaitu sebesar 10,75 individu/ekor. Berdasarkan tabel 1 nilai prevalensi Trichodina sp. pada benih ikan gurami yang diperiksa yaitu $37,33 \%$. Hal ini menunjukkan bahwa dari 150 ekor benih ikan gurami yang diperiksa terdapat 56 ekor benih ikan gurami yang terinfeksi serangan Trichodina sp. Nilai tersebut lebih rendah dibandingkan prevalensi benih ikan gurami pendederan I yang terserang Trichodina sp. dari Desa Luwung, Kecamatan Rakit, Kabupaten Banjarnegara menurut Utami (2015) yaitu sebesar $100 \%$ dan Desa Beji Kecamatan Kedungbanteng Kabupaten Banyumas dengan prevalensi mencapai 100\% (Nurochmah, 2016). Nilai prevalensi hasil penelitian juga lebih rendah bila dibandingkan dengan nilai prevalensi Trichodina sp. pada benih ikan gurami pendederan II yang dijual di TPI Purbalingga oleh Amirudin (2015) yaitu sebesar $40 \%$. Berdasarkan nilai prevalensi yang diperoleh pada penelitian ini, maka prevalensi Trichodina sp. yang ditemukan masuk ke dalam kategori commonly atau umum, Hasil pengamatan terhadap kegiatan pemeliharaan benih ikan gurami di Pasar Ikan Purwonegoro Kabupaten Banjarnegara menunjukkan bahwa prevalensi dan intensitas Trichodina sp. cukup tinggi. Hal ini pada kenyataannya di lokasi penjualan, penjual kurang memperhatikan kondisi lingkungannya (lingkungan perairan yang buruk dan padat tebar benih yang tinggi) atau mungkin dari tempat asal ikan (petani) juga kurang memperhatikan lingkungan perairannya misalnya tidak memperhatikan kepadatan ikan dalam kolam pemeliharaan. Kepadatan ikan yang tinggi dapat menyebabkan ikan menjadi stres. Kolam atau tempat pemeliharaan ikan dengan kepadatan ikan yang tinggi, dapat menyebabkan ikan akan saling bersinggungan satu dengan lainnya, sehingga akan terjadi penularan ektoparasit dengan cepat. Kolam yang tenang, bersinggungan satu dengan lainnya, sehingga akan terjadi penularan ektoparasit dengan cepat. Kolam yang tenang, tergenang, dan tidak berarus memungkinkan infeksi Trichodina sp. lebih tinggi dibandingkan dengan kolam yang berarus deras (Zheila, 2013 ). Faktor lain yang mempengaruhi tinggi rendahnya nilai intensitas dan prevalensi Trichodina sp. yaitu kandungan bahan organik dan kepadatan bakteri. Menurut Nugrayani et al (2011) kandungan bahan organik dan kepadatan bakteri dalam perairan merupakan suatu indikator biologis yang dapat digunakan untuk menggambarkan kualitas pemeliharaan benih ikan secara umum. Peran bakteri sebagai dekomposer bahan organik juga mempunyai peranan penting dalam jaring makanan yaitu sebagai mangsa organisme protozoa seperti Trichodina sp. Apabila jumlah bakteri di kolam tinggi, maka jumlah Trichodina sp juga tinggi.

Nilai intensitas dan prevalensi Trichodina sp. juga dapat dipengaruhi oleh ukuran tubuh dan umur ikan. Menurut Rustikawati et al. (2004), serangan ektoparasit pada ikan akan menurun sejalan dengan bertambahnya umur dan ukuran ikan. Semakin besar ukuran ikan maka sistem ketahanan tubuh ikan akan semakin baik. Kondisi ketahanan tubuh ikan yang berukuran benih masih lemah dan sangat rentan terhadap perubahan lingkungan sehingga lebih mudah terserang parasit. Jumlah intensitas Trichodina sp. yang rendah tidak terlalu mempengaruhi kesehatan ikan. Zheila (2013), menyatakan bahwa Trichodina sp. mempunyai peran penting dalam proses budidaya ikan karena parasit ini menurunkan daya tahan tubuh ikan jika infeksi Trichodina sp. tinggi. Selain itu, Trichodina sp. dapat menyebabkan terjadinya infeksi sekunder. Kerusakan pada permukaan ikan yang diakibatkan oleh Trichodina sp. dapat memunculkan infeksi sekunder seperti bakteri dan pathogen lainnya. Hasil penelitian jumlah 
Trichodina sp. pada setiap organ tubuh benih ikan gurami disajikan pada tabel 2.

Tabel 2. Jumlah Trichodina sp. yang menginfeksi benih ikan gurami Pendederan I pada setiap organ

\begin{tabular}{|c|c|c|c|c|c|c|c|}
\hline \multirow[b]{2}{*}{ Sampling ke } & \multicolumn{6}{|c|}{ Organ Tubuh } & \multirow[b]{2}{*}{ Jumlar } \\
\hline & Sirip ekor & $\begin{array}{c}\text { Sirip } \\
\text { punggung }\end{array}$ & $\begin{array}{l}\text { Sirip } \\
\text { dada }\end{array}$ & $\begin{array}{l}\text { Sirip } \\
\text { anal }\end{array}$ & Insang & Lendir & \\
\hline I & 18 & 20 & 62 & 24 & 10 & 129 & 281 \\
\hline II & 17 & 16 & 12 & 4 & 20 & 76 & 144 \\
\hline III & 6 & 5 & 13 & 3 & 8 & 113 & 148 \\
\hline Total & 41 & 41 & 87 & 31 & 38 & 318 & 573 \\
\hline
\end{tabular}

Jumlah total Trichodina sp. yang ditemukan pada benih ikan gurami sebanyak 573 individu. Hasil penelitian menunjukkan bahwa Trichodina sp. terdapat hampir pada seluruh organ tubuh benih ikan gurami yang diamati yaitu, sirip ekor, sirip punggung, sirip dada, sirip anal, insang dan lendir. Hal ini sesuai dengan pernyataan Riko et al. (2012), bahwa Trichodina sp. dapat menginfeksi lebih dari satu bagian tubuh ikan yaitu, lendir, sirip, dan insang. Trichodina sp. pada benih ikan gurami sebagian besar ditemukan pada lendir dari permukaan tubuh ikan yaitu sebanyak 318 individu dan sirip dada sebanyak 87 individu. Trichodina sp. lebih banyak ditemukan pada lendir ikan disbanding dengan organ tubuh lainnya seperi sirip dan insang. Tinginya jumlah Trichodina sp. pada permukaan tubuh benih ikan gurami disebabkan karena lendir merupakan bagian yang paling luas dibandingkan organ tubuh lainnya dan memiliki kemungkinan terinfeksi yang lebih tinggi. Sari (2015), menyatakan bahwa permukaan tubuh ikan berhubungan langsung dengan lingkungan yang memudahkan serangan ektoparasit termasuk Trichodina sp.

Menurut Zheila (2013) menyatakan bahwa ikan memiliki sistem antibodi berupa sel darah putih (leukosit) terhadap patogen penyakit yang menyerang tubuh inang. Jika sel darah putih tersebut tidak bekerja dengan baik, dan apabila ikan terinfeksi Trichodina sp., maka ikan akan mengeluarkan banyak lendir (mucus). Jumlah Trichodina sp. lebih banyak terdapat pada permukaan tubuh ikan dari pada organ lainnya karena banyak mengandung mucus danjaringan epitel yang merupakan tempat hidup yang baik bagi ektoparasit dan tempat mencari makanan. Sirip dada merupakan organ tubuh kedua yang banyak ditemukan Trichodina sp. pada benih ikan gurami. Menurut Rokhmani (2015), letak sirip dada berdekatan dengan operculum sebagai jalur masuk oksigen ke yang dibutuhkan Trichodina sp. untuk kepentingan hidupnya sehingga Trichodina $\mathrm{sp}$. terakumulasi pada bagian sirip dada. Menurut Zheila (2013), infeksi Trichodina sp. jarang terjadi pada insang ikan. Zheila (2013), menyatakan bahwa intensitas Trichodina sp. pada sirip lebih sedikit karena pada organ ini hanya terdapat sedikit makanan bagi Trichodina sp.

Ikan yang terinfeksi Trichodina sp. biasanya ditandai dengan beberapa gejala, diantaranya yaitu iritasi pada kulit, produksi lendir yang berlebih, insang pucat, nafsu makan menurun, sirip ekor rusak dan berwarna kemerahan akibat pembuluh darah kapiler pada sirip pecah, hingga menyebabkan kematian (Irianto, 2005). Sampel benih ikan gurami yang diteliti ini menunjukkan beberapa gejala ringan, seperti lepasnya sisik dari bagian anggota tubuh ikan, dan insang berwarna pucat. Namun apabila gejala infeksi Trichodina sp. ini tidak segera ditangani dengan baik, dikhawatirkan dapat menjadi pemicu penyebaran penyakit lain selain Trichodina sp. dari Pasar Ikan Purwonegoro, Kabupaten Banjarnegara ke beberapa daerah sentra penjualan benih ikan gurami lainnya.

Karakter morfometrik Trichodina sp. yang menyerang benih ikan gurami pendederan I diperoleh dengan mengukur diameter tubuh, diameter cincin dentikel, diameter dentikel, lebar membran, diameter disk perekat (adhesive disc), dan jumlah dentikel. Jumlah Trichodina sp. yang diukur sebanyak 90 individu Trichodina sp. yang menginfeksi benih ikan gurami dapat dilihat pada tabel 3.

Tabel 3. Karakteristik morfometrik Trichodina sp. pada benih ikan gurami pendederan I (dalam $\mu \mathrm{m}$ )

\begin{tabular}{ll}
\hline Karakteristik & Kisaran (rata-rata \pm sd) \\
\hline Diameter : & $47,5-112,5$ \\
Tubuh & $22,5-47,5$ \\
Cincin dentikel & $12,5-42,5$ \\
Dentikel & $37,5-65$ \\
Disk perekat (adhesive disc) & \\
Jumlah : & $13-28$ \\
Dentikel & $2,5-7,5$ \\
Lebar membran & 90 \\
Jumlah individu parasit yang diukur &
\end{tabular}


Identifikasi Trichodina sp. tidak hanya dilakukan dengan melihat ukuran morfometrik, tetapi juga dilakukan pengamatan meristik pada bentuk dentikel, letak dentikel, bentuk ray dan blade. Hasil identifikasi Trichodina sp. pada penelitian ini dapat ditunjukkan pada gambar 1.

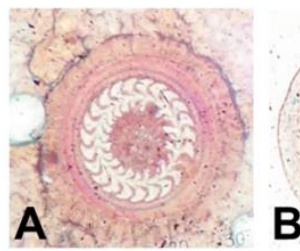

Gambar 1. Hasil

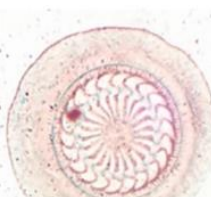

B

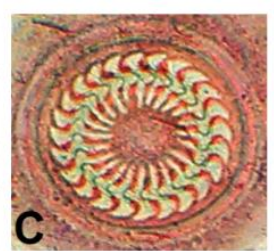

mikroskopis Trichodina sp. yang ditemukan pada benih ikan gurami pendederan I perbesaran $400 x$ A. T. acuta B. T nigra C. T heterodentata

Hasil pengamatan karakteristik morfometrik Trichodina sp. pada benih ikan gurami menunjukkan bahwa Trichodina sp. memiliki perbedaan karakteristik yang diketahui dari dari ukuran diameter tubuh, diameter cincin dentikel, diameter dentikel (radial pin per dentikel), lebar membran dan jumlah dentikel. Jenis Trichodina $\mathrm{sp}$. hasil penelitian dapat diidentifikasi berdasarkan Duncan (1977); Van dan Basson (1986); dan Amirudin (2015). Menurut Padua et al. (2012), jenis Trichodina heterodentata memiliki karakteristik diameter tubuh 71-106 $\mu \mathrm{m}$; diameter adhesive dic 47-63 $\mu \mathrm{m}$; diameter cincin dentikel 26-37 $\mu \mathrm{m}$; lebar membran 2,7 $\mu \mathrm{m}$; dan jumlah dentikel 20-27. Sedangkan menurut Woo (2006), jenis Trichodina heterodentata memiliki karakteristik dengan kisaran diantaranya diameter adhesive disc 38-82 $\mu \mathrm{m}$; diameter cincin dentikel 23-51 $\mu \mathrm{m}$; dan jumlah dentikel 20-30. Trichodina nigra memiliki karakteristik dengan kisaran diantaranya diameter cincin dentikel 19-39 $\mu \mathrm{m}$; diameter adhesive dic 32-65 $\mu \mathrm{m}$, dan jumlah dentikel 25-29. Menurut Basson (2010), Trichodina nigra memiliki karakteristik diameter tubuh 61-79 $\mu \mathrm{m}$; diameter cincin dentikel 27-33 $\mu \mathrm{m}$; diameter adhesive dic 43-54 $\mu \mathrm{m}$, dan jumlah dentikel 18-29. Trichodina acuta memiliki karakteristik dengan kisaran diantaranya diameter tubuh 42,5-57,5 $\mathrm{mm}$; diameter cincin dentikel 22,5$32,5 \mu \mathrm{m}$; diameter adhesive disc 40-52,5 $\mu \mathrm{m}$; lebar membran 2,5-5,5 $\mu \mathrm{m}$ dan jumlah dentikel 19-23 (Amirudin, 2015).

Hasil identifikasi menunjukkan bahwa jenis Trichodina heterodentata, Trichodina nigra dan Trichodina acuta yang dikemukakan oleh Van dan Basson (1986); Basson (2010) dan Amirudin (2015) berada dalam kisaran karakteristik morfometrik Trichodina sp. yang diamati dari benih ikan gurami di Pasar ikan Purwonegoro Kabupaten Banjarnegara seperti terlihat pada tabel 2. Oleh karena itu, dapat diduga Trichodina sp. yang ditemukan pada benih ikan gurami dari Pasar Ikan Purwonegoro Kabupaten Banjarnegara terdapat tiga jenis Trichodina sp.
(Gambar 1) yaitu Trichodina acuta (A), Trichodina nigra (B) dan Trichodina heterodentata (C). Karakteristik morfometrik $T$. heterodentata pada benih ikan gurami dapat dilihat pada gambar 1 . Berdasarkan penelitian Duncan (1977) dan Van dan Basson (1986), menunjukkan bahwa karakteristik morfometrik $T$. heterodentata berada dalam kisaran karakteristik morfometrik Trichodina sp. pada benih ikan gurami seperti terlihat pada Tabel 3, Oleh karena itu, dapat disimpulkan bahwa Trichodina sp. yang ditemukan adalah jenis T.heterodentata. T. heterodentata merupakan jenis Trichodina kosmopolitan (Padua et al., 2012). Trichodina heterodentata pertama kali diidentifikasi oleh (Woo, 2006). Martins et al. (2010), mengemukakan bahwa sebanyak 43 spesies pisces dari 14 famili telah diketahui menjadi inang bagi parasit ini. Jenis Trichodina sp. lain yang ditemukan dalam penilitian ini adalah $T$. nigra. Gambar 1, B menunjukkan hasil pengamatan $T$. nigra pada permukaan tubuh benih ikan gurami. Pengukuran karakter morfologi dilakukan dengan menggunakan mikroskop cahaya yang dilengkapi mikrometer. Perbesaran yang digunakan adalah 400X. Karakteristik morfometrik T. nigra dari hasil penelitian dibandingkan dengan $T$. nigra dari hasil penelitian Woo (2006); dan Nurohmah (2016).

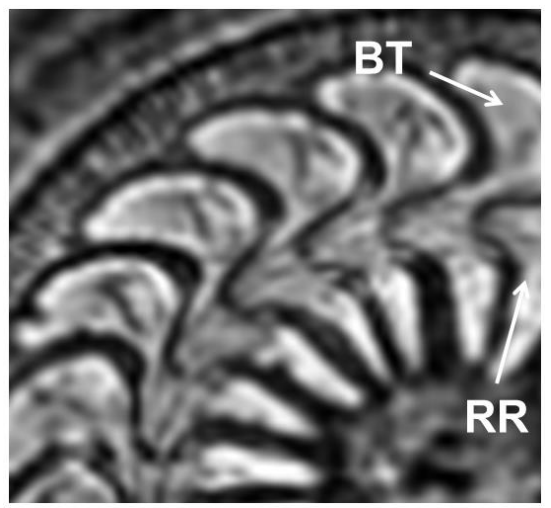

Gambar 2. Skematik morfologi dentikel T. nigra (Van \& Basson, 1986) : BT, Blade apex tumpul; $\mathrm{RR}$, Ray runcing.

Ujung blade apex dentikel Trichodina nigra berbentuk tumpul dan pendek, namun denticle ray dari Trichodina nigra berbentuk meruncing lurus. Hasil pengukuran karakterikstik morfometrik pada 90 sampel ditemukan Trichodina sp. dengan ciriciri seperti Trichodina nigra sebanyak 4 sampel. Berdasarkan penelitian Lom (1961); dan Nurohmah (2016), menunjukkan bahwa karakteristik morfometrik $T$. nigra berada dalam kisaran karakteristik morfometrik Trichodina sp. pada benih ikan gurami seperti terlihat pada Tabel 3. Oleh karena itu, dapat disimpulkan bahwa Trichodina sp. yang ditemukan adalah jenis $T$. nigra. Trichodina nigra pertama kali diidentifikasi oleh Van dan Basson (1986), menyatakan bahwa Trichodina nigra merupakan parasit jenis Trichodina sp. yang paling umum ditemukan pada 
permukaan tubuh dan insang beberapa ikan air tawar. Jenis Trichodina sp. lain yang juga ditemukan adalah $T$. acuta. Gambar $1 \mathrm{~A}$, menunjukkan hasil pengamatan $T$. acuta pada permukaan tubuh benih ikan gurami. Pengukuran karakter morfologi dilakukan dengan menggunakan mikroskop cahaya yang dilengkapi mikrometer. Perbesaran yang digunakan adalah 400X. Karakteristik morfometrik T. acuta dari hasil penelitian dibandingkan dengan $T$. acuta dari hasil penelitian Amirudin (2015); Woo (2006). Berdasarkan penelitian Amirudin (2015); Van dan Basson (1986) menunjukkan bahwa karakteristik morfometrik $T$. acuta berada dalam kisaran karakteristik morfometrik Trichodina sp. pada benih ikan gurami seperti terlihat pada Tabel 6, oleh karena itu, dapat disimpulkan bahwa Trichodina sp. yang ditemukan adalah jenis $T$. acuta. T. acuta merupakan jenis Trichodina sp.

\section{Daftar Referensi}

Amirudin, A. 2015. Prevalensi dan Variasi Morfometrik Trichodina sp. pada Benih Ikan Gurami (Osphronemus gouramy Lac.) Pendederan II yang Dijual di Tempat Penjualan Ikan (TPI) Purbalingga. Skripsi. Fakultas Biologi Universitas Jenderal Soedirman. Purwokerto

Basson, L., 2010. First records of Trichodinid ectoparasites (Ciliophora: Peritrichia) from included freshwaterfishes in Tasmania, Australia, with comments of Pathogenity. Acta Parasitologica, 49(3), pp. 253-265.

Dana, D. I., Effendi, K., Sumawidjaja dan Hadiroseyani, Y. 2002. Parasit Trichodina pada Benih Ikan Betutu (Oxyeleotris marmorata). Jurnal Akuakultur Indonesia. IPB. Bogor:1.pp 5-8.

Duncan, B.L., 1977. Urceolariid ciliates, including three new species, from cultured Philippines fishes. Transactions of the American Microscopical Society, 96, pp.7681.

Google

Maps.

2016. https://www.google.co.id/maps/. Diakses tanggal 27 Januari 2016.

Himawati, S. 2011. Intensitas dan Serangan Ektoparasit pada Benih Ikan Gurami (Osphronemus gouramy Lac.) di Pasar Ikan Purwonegoro Kabupaten Banjarnegara. Skripsi. Fakultas Biologi Universitas Jenderal Soedirman. Purwokerto

Irianto, A. 2005. Patologi Ikan Teleostei. UGM Press. Yogyakarta. yang ikan air tawar yang ditemukan secara luas di perairan Eurasia, Amerika Utara, Filiphina dan Afrika. Daerah pilihan T. acuta untuk menginfeksi inang yaitu pada bagian permukaan kulit atau lendir tubuh ikan. T. acuta jarang ditemukan pada bagian insang ( Woo, 2006).

\section{Simpulan}

Berdasarkan hasil dan pembahasan, maka dapat diambil kesimpulan Intensitas Trichodina sp. pada benih ikan gurami pendederan I yang dijual di Pasar Ikan Purwonegoro Kabupaten Banjarnegara tergolong cukup tinggi yaitu mencapai 10,97 individu/ekor. Trichodina sp. yang ditemukan menunjukkan adanya variasi morfometrik dan diduga terdapat beberapa jenis Trichodina sp. diantaranya $T$. heterodenta, $T$. nigra, dan $T$. acuta.

Kabata, Z., 1985. Parasites and Diseases of Fish Cultured in The Tropics. London: Taylor and Franscis.

Martins, M.L., Marchiori, N. Nunes, G. \& Rodrigues, M.P., 2010. First record of Trichodina heterodentata (Ciliophora: Trichodinidae) from channel catfish, Ictalurus punctatus cultivated in Brazil. Braz. J. Biol., 70(3), pp. 637-644.

Nikolic, V., Simonov, P. \& Vesna, P., 2003. Preference of Trichodinids (Ciliata, Petrichia) occuring on fish-pond carp for particular organs and some morphological implications. Acta Veterinaria, 53(1), pp. 4146.

Nurochmah, H.S. 2016. Kelimpahan dan Variasi Morfometrik Trichodina Sp.pada Benih Ikan Gurami (Osphronemus Gouramy Lac.)Di Kolam Budidaya Desa Beji KecamatanKedungbanteng Banyumas. Skripsi. Tidak dipublikasikan. Fakultas Biologi. Universitas Jenderal Soedirman. Purwokerto

Nugrayani, D., Agung, C.S., dan Hamdan, S. 2011. Prevalensi Trichodina Pada Kondisi Lingkungan Perairan Berbeda. OmniAkuatika 3(13) : $43-48$

Rokhmani. 2009. Keragaman dan Tingkat Serangan Ektoparasit pada Gurame (Osphronemus gouramy Lac.) Tahap Pendederan I dengan Ketinggian Lokasi Pemeliharaan yang Berbeda. Jurnal Biotika 7 (2) : 87-93.

Rokhmani, Edy R dan Endang A.S. 2012. Pengaruh pengangkutan benih gurami "delivery order" terhadap jumlah dan jenis ektoparasit. PROSEDING SEMNASKAN 2012 Jur. Perikanan Fakultas Pertanian UGM Jogjakarta 
Rokhmani, Edy R dan Titi C.2015.Hubungan Kekerabatan Trichodina sp. Pada Benih Ikan Gurami Sebagai Upaya Pengendalian Dini di Provinsi Jawa Tengah. Tidak dipublikasikan. Purwokerto : UNSOED

Rustikawati, I., Rostika, R. Iriana, D., dan Herlina, E. 2004. Intensitas dan Prevalensi Ektoparasit Pada Benih Ikan Mas (Cyprinus carpio L.) yang Berasal dari Kolam Tradisional dan Longyam di Desa Sukamulya Kecamatan Singaparman Kabupaten Tasikmalaya. Akuakultur Indonesia. Vol. 3 (3) : 33-39.

Riko, Y.A., Rosidah \& Herawati, T., 2012. Intensitas dan Prevalensi Ektoparasit pada Ikan Bandeng (Chanos chanos) dalam Karamba Jaring Apung (KJA) di Waduk Cirata Kabupaten Cianjur Jawa Barat. Jurnal Perikanan dan Kelautan, 3 (4), pp. 231-241.

Sari, N.S. 2015. Kelimpahan dan Variasi Morfometrik Trichodina Sp.pada Benih Ikan Cupang (Betta splendens Regan)yang Dibudidayakan "Enjoy Akuarium" Dukuwaluh Kecamatan Kembaran Banyumas. Skripsi. Tidak dipublikasikan. Fakultas Biologi. Universitas Jenderal Soedirman. Purwokerto
Utami, S. T. 2015. Intensitas Trichodina sp. pada Benih Ikan Gurami (Osphronemus gouramy L.) Di Kolam Budidaya Desa Luwung Kecamatan Rakit Banjarnegara. Skripsi. Fakultas Biologi Universitas Jenderal Soedirman. Purwokerto

Van, A. J. G. and Basson, L. 1986. Trichodinid (Ciliophora: Peritrichida) Ectoparasites of Cultured Cichlids from Taiwan. Bulletin Institute.Zoology Academy Sinica, 25. pp 135-139.

Windarto, R., Adiputra, Y.T., Wardiyanto \& Efendi, E. 2013. Keragaman Karakter Morfologi Antara Trichodina Nobilis dan Trichodina Reticulata pada Ikan Komet (Carrasius Auratus). e-Jurnal Rekayasa dan Teknologi Budidaya Perairan, 1(2), pp.117-126

Zheila, P. R. N. 2013. Prevalensi dan Intensitas Trichodina sp. pada Benih Ikan Nila (Oreochromis niloticus) di DesaTambakrejo, Kecamtan Pacitan, Kabupaten Pacitan. PAPER. Fakultas Matematika dan IImu Pengetahuan Alam. Institut Teknologi Sepuluh Nopember Surabaya. Surabaya. pp 1-11. 